\title{
Impact of Technological Advancement on Employee Performance in Banking Sector
}

\author{
Muhammad Imran (Corresponding author) \\ Department of Management Sciences, The Islamia University of Bahawalpur \\ Email: imran_imranb2001@yahoo.com \\ Nadeem Maqbool and Huzaifah Shafique \\ Department of Management Sciences, The Islamia University of Bahawalpur
}

Doi: 10.5296/ijhrs.v4i1.5229 URL : http://dx.doi.org/10.5296/ijhrs.v4i1.5229

\begin{abstract}
Purpose: The purpose of this study is to check the impact of technological advancement on employee performance in banking sector.

Methodology: This paper was completed with the help of extensive literature on technological advancement and employee performance available on the databases and websites. Primary data has been used in this paper to check the impact of technological advancement on employee performance. SPSS 16 software package is used to analyze the employee responses and statistical technique Regression analysis is used to check the impact of technological advancement on employee performance.

Findings: Total of 140 questionnaires has been distributed among different banks and out of which 100 were get completed and returned. After analyzing the data very efficiently, we find that technological advancement has significant impact on motivation and training of employees. Motivation has significant impact on employee performance but training has no significant impact on employee performance. Moreover as the concerned for technological advancement and employee performance, there is significant relationship among them.
\end{abstract}

Research limitations / Implications: More research will be require on this theory "impact of technological advancement on employee performance in banking sector"

Type: Quantitative Paper

Key Words: Technology advancement, employee performance, banks 


\section{Introduction}

In this modern world of repaid high-technology changes, technological advancement will continue to accelerate the future. Technological advancement change the organizational policies and strategies (Hampel and Martinsons, 2009).In any organization, most of challenges are generated by competition, advanced technology, enhancing employee efficiency and repaid growth, new leadership and management (Madsen et al., 2005).Most of the research has shown that employee attitude and behaviours need to be develop for successful organizational performance (Bernerth, 2004).

Most of the firms involved the employee in management, working for technological advancement implementation. Firms invest on employees training to improve the employee knowledge and skills and development of employees prior to the introduction of new technology. You must ensure that workers ' union to consider the effects of technological advancement on their own physiology. It is clear that the staff who worked under both the old and new systems have expressed less positive attitudes about their jobs, and these attitudes circulated to the organization because it has become less committed and more likely to leave. So firms must motivate the employees to adopt the new technology and also organization gives incentive to employee for better performance (Dauda \& Akingbade, 2011).

Moreover organizations purchase the advance technological tool for improving the employee's performance, facilitated job-tasks, improved communication, increased efficiencies, and higher-levels of effectiveness in work management. The introduction of advance technology has changed the way of performing job. Technological advancement improved the employee performance as well as less the employee working effort and task completion time.

New technology is not only essential for company or government, it is also important for nation. Companies cannot run with old technologies. Technology increase human performance when human or employees use technology for the benefits of the organization and use with ethical values. Individual person cannot adopt technology easily and on the other side group of people can adopt technology easily. Computer is a greatest invention; it is useful only in that case when employees use it for their work. New technology can be used for both purposes for break or for make purpose. Employee work load reduce through technological advancement. Number of employees to perform one task is also reduced. Companies require not much more employees to perform one job. Human effort is also reduced through technological advancement. Single employee can perform its job without any hurdle.

Human Resource Management use the advance technologies equipment to check and evaluate the employees output or performance. Human Resource Management decides to leverage emerging technologies to drive productivity and the management of human capital will make the difference between a mediocre HR department and one that is truly a business partner. Current technology trends that will impact HR are outsourcing, advances in technology, and a continued focus on measuring the value that HR brings to the organization. The role of the HR professional has changed fundamentally as a result of technology. The 
core competencies that have developed are mastery of HR technology, strategic contribution, personal credibility, HR delivery, and business knowledge.

\section{Literature Review}

\subsection{Technological Advancement and Employees Performance}

Technological advancement is the process of combining and reorganizing knowledge to generate new ideas. The development of technology has an impact on firm performance (Mumford, 2000). Technological advancement comes from internal advancement (Pavitt, 1990), and internal advancement comes from employee capability. So there is a close relationship between technological advancement and employee performance (Huselid, 1995).

Technologies can only lead to increased productivity or improve performance when combined with other resources effectively by human resources or when done effectively, and use technology productively and ethically (Dauda \& Akingbade, 2011).

Advancement makes employees more effective and firm more efficient (Lawless and Anderson, 1996). Technological advancement can improve firm performance as well (Li and Deng, 1999).

Employee can more rapidly acquire new knowledge and further advancement competencies through training (Chi et al., 1989). Motivation of the employee has direct influence on technological advancement (Hennessey and Amabile, 1998).

Employee's performance is closely linked with technological advancement. Technological advancement can be managed effectively through employees.

Resource-based theory suggests that a firm's resources are extremely important for the firm's development, and that human capital is a key resource of a firm. The function of this resource depends on the employees' ability and enthusiasm, and on efficient human resource management (Mumford, 2000).

Technological advancement has enormous influence on employee performance (Nohria and Gulati, 1996). Technological advancement is important factor for influencing the improvement of performance (Hitt et al., 1997). Most of studies have repeatedly shown a positive relationship between a firm's technological advancement and performance, and concluded that technological advancement is important for employee performance (Foster, 1986).

\subsection{Training and Technological Advancement}

Training must exist in every organization; training corrects deficiencies known as the time of employee appointment and enables employees to face arising advancement challenges as well. Training not only motivate to employees but also working as a catalyst to doing any new task at work place (Amagada, 2006).

Becker (1964) suggests that employee training allows employee to use the new skills. Firm's employee with more advancement knowledge is important resources of the firms and they are 
continually attained new knowledge and skill for development of new technology. Training can improve the employee knowledge, competencies of advancement. Advancement involves the production of new ideas and that ideas can be implemented to solve some significant novel problem (Mumford and Gustafson, 1998). Training results, employees can more rapidly acquire new knowledge, and can increase their advancement ability (Chi et al., 1989). Moreover, the people who have broad expertise and knowledge may produce more technological advancement (Mumford, 2000).

Organizations can improve its employee's skills and efficiency through training and development. Research shows that investment on employees in the field of decision making, teamwork tasks and in problem solving results shows that firm's outcome level increases. In some organizations research proves that training is positively correlated with employee output. Training is not short term process. It is nonstop and systematic process. Organizations have done employee's analysis and also asses the need of firm. Then specified training program is adapted after that analysis. Organization adapts that method of training which is consistent with employees and as well as fulfil the goals of organization (Singh \& Mohanty, 2012).

Training is not only beneficial for employees to enhance their abilities and skills regarding job but also important for organizations to achieve their goals. A skilful human resource cannot be copied. Organizations arrange training programs to increase employee's skills that are required for doing jobs. One of the main motives of organizations is to produce values and profit for their shareholders by facilitating their customers by providing unique products and high quality services to their customers. To achieve competitive edge over competitor it is necessary for organizations to manage and develop highly skilled workers. For that purpose organizations arrange different types of training programs for their employees. Training programs not only fulfil firms desires to achieve their goals but also meets individuals own desires in the form of money, promotion and being well known in eyes of manager(Sultana, Irum, Ahmed, \& Mehmood, 2012).

Due to global environment firms are encountered with different sort of problems that they never faced before. More competencies regarding job are required that are essential for achieving organizations goals. Firms should adopt these changes and equip them with latest technology and develop their abilities to use latest technology (Farooq \& Khan, Impact of Training and Feedback on Employee Performance, 2011).

Technologies advancement to change the work nature and work task as well so employee requiring new knowledge and skill to doing the new task effectively. Training is one of effective strategy to give the new knowledge and skill to employee to doing a job effectively (Goldstein and Gilliam, 1990).Most recent studies shows that organization face two factor one is old age workforce second is increasing introduced a new technologies, so training is very important for further new technology introduction as well, such as web-based operation, computerized intelligent systems, and other task technologies (Colquitt et al., 2000). 


\subsection{Motivation and Technological Advancement}

Motivation is define as change in behaviour not attribute to stable individual differences. Motivation mean is characteristic of an individual willing to expend efforts toward a particular set of behaviour (Quinone's, 1997).

Employee motivation having a direct effect on technological advancement (Orpen, 1994).Employee require organizational incentives to enhance the advancement process (Harsanyi, 1969).The incentives or the employee can be divided into material incentives and non-material incentives; material incentive is mainly economic gain, and non-material incentive is mainly social acceptance. Material and non-material incentives can meet the different needs of employees in technological advancement activities (Gruber, 1996).

Motivation is an internal feeling that comes from inside. When employees are motivated towards their jobs, they are motivated to do more work. When a person is not motivated by self, he or she may be fired or likely not to get promoted further. For this reason, it is necessary to provide such a workplace to the employees so that they feel motivated and perform better and better. Research shows that motivated employees play a vital role in the success of the organizations. Motivation is an important factor which describes performance. It is a driving force contained by the individuals). It is concerned with the behaviours of the individuals and people act to achieve something to satisfy their needs (Saeed \& Asghar, 2012).

Motivation is a very important from an organizational point of view because it transforms human resources into action. And this improves the efficiency level of the employees and it leads to achieve organizational goals Motives are the key to human behaviour. It plays an important role in performance and other activities and as such the manager should know what motivation is and how subordinates can are motivated towards performance (Ali, Abrar, \& Haider, 2012).

Job is not performed properly until and unless employees are motivated and proper environment of work is provided to them. There are two types of motivation i.e. extrinsic motivation and intrinsic motivation. Both types of motivation affect individual performance. Rewards in the form of compensation, bonuses affect extrinsic motivation while verbal appreciation affects intrinsic motivation. The main factors that motivate the employee to work harder and better performance are Salary/Bonuses, Organizational Culture, Involvement of Employees, Employee Management Relationship, Flexi Time/ Working Hours, Promotion (Chintalloo \& Mahadeo, 2013).If employees motivate than adopted the new technology and as well as new work places changes.

\subsection{Motivation and Employee Performance}

There is much evidence to suggest that making people feel valued, and that their contribution is important and recognized, is the best basis for a committed and motivated workforce that will go the extra mile. When employees understand that their achievements and efforts are recognized and rewarded they will perform better. Our aim is to facilitate a change in culture with regard to pay and to transform the way people are managed, motivating employees to 
succeed and providing more clarity about their goals. Improvements in performance and raising standards are both key components that contribute to an organization's success and help us to ensure we have the very best people in the right roles and that they are motivated to stay (Rudge, 2011).

In this literature motivation is the variable which can affect employee performance in the organization. Here we have another variable which is motivation and we have to check its impact on the employee performance whether increase in motivation or low motivation increases or decreases the performance of the employee in the organization. Impact of motivation on employee performance this is the aim of this research. There are other variables also where each of them has great impact on the performance of the employees in the particular organization in which they are working just like technology, motivation, management behaviour and working environment. (Khan, 2012)

To influencing employees motivation is very much important to accomplish organization as individuals predetermine goals. To achieve unmet and specific needs this inner drive and motivates employees to form the positive behaviour in the organization which have quite positive impact on the working environment. Acknowledging employees on their efforts and work while they are on their duties, giving them healthy work environment and according to their needs building pleasant job design with this little support on behalf of organizations enables them to achieve their objectives efficiently. In this way performance is increased by motivation. (Khan, 2012)

Focus on the performance of the organization and employee motivation has been working in-depth study of the recent times. Organizations are more concerned about how well motivate their employees to achieve their mission and vision. In the public and private sector organizations are increasingly aware of employees, motivation, and increase productivity. Workers inspiration is a policy of a management to increase the effective operation of the management staff and associations. Motivational staff is quick to respond and they provide directions to their efforts towards the goals and objectives of the organizations. Motivation develops a more successful organization, because employees are constantly looking provoked improved approach to do a job. The staff will do their best work even in severe cases, it is one of the most stable and greasy staff challenges, which can inspire them to become possible. (U.S., 2013)

Several greatest challenges for the organization moved downward knowledge from the accumulation of knowledge, practice it in the past, is a good return path to effective management practices to dry. Staff is excited hoarding, because knowledge of competitive advantage, which gave them individuals within their organization. People think that if knowledge of the organization to provide sources of competitive advantage, it also provides individuals within an organization's competitive advantage. From the employee's perspective, companies are seeking them to share that they want to earn positions and financial incentives and progress they hold. (Milne, 2007)

Learn how to motivate employees is one of the key challenges for managers. Although it is not directly inspire others, but it is important to know how to influence people's motivation to 
do with employees to determine their own welfare and the overall objectives of the organization. (Milne, 2007)

The basic assumption motivations include: the ability to get people to act responsibly, the naturally aspirated learning and understanding things, and the desire to do good work and entertainment. With evidence-based theory of human motivation, self-determination theory (SDT) to solve the cognitive, emotional and psychomotor development of a few basic questions related. Self-awareness, a person's goals and aspirations psychosomatic and emotional wants, life, personal vitality, cultural and social impact on the environment is to determine a person's ability to self-specific key issue is the focus of the SDT. Because motivation assumes a different dimension necessary to consider the motivation and self-control motivation and performance prediction as motivation related issues. (Ankli \& Palliam, 2012)

All areas of behaviour change as a result of the power has been widely reported effort. Deci and Ryan (2002) they present self-determination theory (SDT), the theory of personality maturity and self-motivate behaviour change. SDT is a theory of cognitive evaluation and assessment, which shows the impact of intrinsic motivation extrinsic motivation. Intrinsic motivation is personal happiness derived from the activity itself spontaneously. Extrinsic motivation, in contrast, requires physical or oral reward. Satisfaction with the results of the activity itself is not a cause but a consequence from the outside to the event. (Ankli \& Palliam, 2012)

\subsection{Training and employee performance}

Training helps to overcome gaps between employees and senior level management. It enables employee to participate in decision making and provide active output in decision making. Employee coordination with peer, subordinates and with its senior officers increases after training. These types of steps create better image in front of those think tanks who are working for value maximization of organization. Most important for the organization employee performance increases after training. Organizations which are working around the globe. These organizations are more concerned about their employees. These type of organizations launch different type of training programs for value creation into their employees. Global organizations train their employees in aspect of working field. Training not only develop employees mental ability but also after training employees can take benefit physically such as active participation in decision making can release it mental disturbance(Farooq \& Khan, 2011).

Employees performance is also relate with commitment of employees with organization. High commitment leads to high performance and low commitment leads toward low commitment. So in simple when employees are so committed with organization we will determine from that employee's performance is good. Training improves employee's commitment with organization. Commitment can be defined as employees work for organization for long period of time. Training improves skills of employees that thing insist organization to improve benefits and pay of employees. Scholars and researchers accept that training increase commitment of employees with organization but training produce desired 


\section{Macrothink Institute ${ }^{\text {TM }}$}

out comes only in that situation when employees also accept that training program. It means that training is effective only in that when from both sides cooperation occurred. Employees enter in training program with lot of expectations when these expectations are not fulfilled; it comes in result of employee's low commitment and high turnover. Because in case of low commitment whenever they got opportunity they will prefer to leave organization (BRUM, 2007).

Training has bigger impact on the performance of employees but training is not only single factor which effect the performance of employees other factors are also here which effect performance of employees. Other factors are employee skills, employee knowledge, motivation and reward. Trained employees are more efficient in group work because they are well known about the expectation of other workers. Employees who take regular training programs are easily accepting changes in organization. Whenever organization launch innovative programs they resistance from those employees who do not attend regular training programs. Trained employees help organization to reduce training cost of other employees. Because when one employee is full trained, he will be capable to train other untrained employees in the organization. Training helps the employees to achieve different task of the organization and vice versa. Training is systematic approach of behaviours that enables employees to change their behaviours according to the norms and values of the organization (Jagero \& Komba, 2012).

Training is used to fill gap between current performance and desired performance after training. Training can be given through different methods such as coaching and mentoring, cooperation between peers. These team works encourage employees to work more for organization. Training is not only useful for employees but it also valuable for organization. It develops competitive edge for organization in the market. Training develops in the employee's self-efficacy which is helpful for superior performance (Elnaga \& Imran, 2013).

\section{Theoretical Framework}

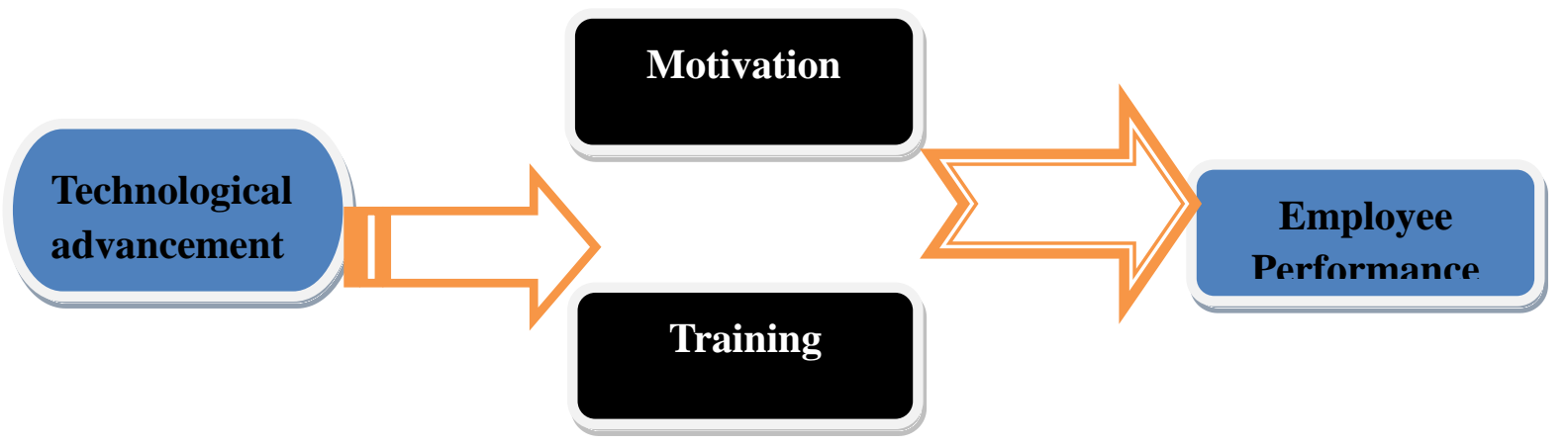




\subsection{Hypothesis}

H0: There is no significant relationship between technological advancement and motivation.

H1: There is significant relationship between technological advancement and motivation.

H0: There is no significant relationship between technological advancement and training.

H1: There is significant relationship between technological advancement and training.

H0: There is no significant relationship between motivation and employee performance.

H1: There is significant relationship between motivation and employee performance.

H0: There is no significant relationship between training and employee performance.

H1: There is significant relationship between training and employee performance.

\section{Research Methodology}

\subsection{Data Collection}

The data collect for this study through primary source. Due to lack of time employees are taken from Bahawalpur Region as the sample research. Firstly employees have been identified and after the willingness of them, questionnaire has been filled by them and the required data has been collected. Total of 140 questionnaires have been distribute among different banks and out of which 100 were get completed and returned. Results are given below...

\section{Results and Discussion}

\begin{tabular}{|l|l|l|l|l|l|}
\hline & Coefficient (B) & $\begin{array}{l}\text { Standard } \\
\text { Error }\end{array}$ & T-Ratio & P value & $\begin{array}{l}\text { Adjusted } \\
\text { R Square }\end{array}$ \\
\hline Constant value & .899 & .234 & 3.848 & .0000 & \multirow{2}{*}{0.133} \\
\hline $\begin{array}{l}\text { Technological } \\
\text { advancement }\end{array}$ & .398 & .099 & 4.031 & .0000 & \\
\hline
\end{tabular}

Independent variable: Technological Advancement

Dependent variable: Motivation

Above table shows there is a significance relationship between technological advancement and motivation. $\mathrm{P}$ value shows that Relationship is highly strong between these two variables. 


\section{Macrothink}

Coefficient value indicate that one unit increase in technological advancement, it will increase .398 points of motivation. Its adjusted $\mathrm{R}$ Square value is 0.133 which indicates that a 13.3 percent change comes in motivation of employees through technological advancement.

\begin{tabular}{|l|l|l|l|l|l|}
\hline & $\begin{array}{l}\text { Coefficient } \\
(\mathrm{B})\end{array}$ & Standard Error & T-Ratio & P value & $\begin{array}{l}\text { Adjusted R } \\
\text { Square }\end{array}$ \\
\hline Constant value & .858 & .274 & 3.135 & .002 & \multirow{2}{*}{0.220} \\
\cline { 1 - 4 } $\begin{array}{l}\text { Technological } \\
\text { advancement }\end{array}$ & .622 & .166 & 5.377 & .0000 & \\
\hline
\end{tabular}

Independent variable: Technological Advancement

Dependent Variable: Training

Above table shows that there is significant relationship between technological advancement and training. P Value indicates that there is highly significance relationship between these variables. Coefficient 0.622 shows that if one percent change occurs in technological advancement, it will cause .622 percent change in training of employees. Its adjusted R Square value is 0.220 which indicates that a 22 percent change comes in training of employees through technological advancement.

\begin{tabular}{|l|l|l|l|l|l|}
\hline & $\begin{array}{l}\text { Coefficient } \\
(\mathrm{B})\end{array}$ & Standard Error & T-Ratio & P value & $\begin{array}{l}\text { Adjusted R } \\
\text { Square }\end{array}$ \\
\hline Constant value & 1.413 & .178 & 7.928 & .000 & \\
\cline { 1 - 4 } Motivation & .210 & .093 & 2.247 & .027 & \multirow{2}{*}{0.039} \\
\hline
\end{tabular}

Independent variable: Motivation

Dependent Variable: Employee Performance

Above table shows that there is significant relationship between motivation and employee performance. Coefficient value indicates that if one unit increases motivation, it will be resulted in increment of .210 points of employee performance. Its adjusted R Square value is 0.039 which indicates that a 3.39 percent change comes in employee performance through employee motivation. 


\begin{tabular}{|l|l|l|l|l|l|}
\hline & $\begin{array}{l}\text { Coefficient } \\
(\mathrm{B})\end{array}$ & Standard Error & T-Ratio & P value & $\begin{array}{l}\text { Adjusted R } \\
\text { Square }\end{array}$ \\
\cline { 1 - 3 } Constant value & 1.899 & .186 & 10.199 & .000 & \\
\cline { 1 - 4 } Training & -.045 & .077 & -0.582 & .562 & -0.007 \\
\hline
\end{tabular}

Independent variable: Training Dependent variable: employee performance

Above table shows that there is insignificant relationship between training and employee performance. $\mathrm{P}$ value 0.562 indicates that training does not have impact on employee performance. In other way we can say that our target population performance is not much influenced through training.

\section{Conclusion}

The study shows that employee performance influenced by technological advancement. Basically, three main variables technological advancement, motivation and training are taken as independent variable to check the employee performance. In first stage, technological advancement is taken as independent variable and motivation and training are taken as dependent variables .and it has been observed that technological advancement has significant impact on both variables motivation and training. In other words, we can say that with the advancement in technology employees of banking sector tend to be motivated to do their work and there is more need of training for employee skills and knowledge about that specific technology. In second stage motivation and training are taken as independent variables and employee performance is taken as dependent variable. And it has been observed that motivation has significant impact on employee performance but as well as concern for training of employee, it is found that training has no significant impact on employee performance. In other words we can say that if employees are motivated towards their work, their performance will be better than those who are not motivated towards their job and about training we can say that training not much influenced the employee performance. In Third stage, technological advancement is taken as independent variable and employee performance is taken as a dependent variable and finds that technological advancement has significant impact on employee performance it means that as technology tend to be advanced, performance of employee enhanced.

\section{References}

1. Ankli, R. E., \& Palliam, R. (2012). Enabling a motivated workforce: exploring. Development And Learning In Organizations , 26 (2), 7-10.

2. Ali, A., Abrar, M., \& Haider, J. (2012). Impact of Motivation on the working performance of employees- A case study of Pakistan. Global Advanced Research Journal of Management and Business, 1 (4), 126-133.

3. Amagada, G. O. (2006). Training needs and methods of training in information 


\section{Macrothink

technology in the oil industry libraries. The Electronic Library, 11-19.

4. Becker, G. (1964), "Human capital”, Chicago University, Chicago, IL.

5. BRUM, S. (2007). What Impact Does Training Have On Employee Commitment And Employee Turnover? Schmidt Labor Research Center Seminar Research Series , 9-11.

6. Bernerth, J. (2004). Expanding our understanding of the change message. Human Resource Development Review, 3(1), 36-52.

7. Colquitt, J.A., LePine, J.A. and Noe, R.A. (2000), "Toward an integrative theory of trainingmotivation: a meta-analytic path analysis of 20 years of research", Journal of Applied Psychology, Vol. 85, pp. 678-707.

8. Chi, M.T.H., Bassock, M., Lewis, M.U., Reitman, P. and Glaser, R. (1989), "Self-explanations: howstudents study and use examples in learning to solve problems", Cognitive Science, Vol. 13,pp. 145-82.

9. Chintalloo, S., \& Mahadeo, J. D. (2013). Effect of Motivation on Work Performance at Ireland Blyth Limited. Proceedings of 8th Annual London Business Research Conference (pp. 01-16). mperial College, London, UK.

10. Dauda, D. Y., \& Akingbade, W. A. (2011). technological change and employee performance in selected manufacturing industry in lagos state of nigeria. Australian Journal of Business and Management Research, 12.

11. Elnaga, D. .., \& Imran, A. (2013). The Effect of Training on Employee Performance. European Journal of Business and Management , 1-11.

12. Farooq, M., \& Khan, M. A. (2011). Impact of Training and Feedback on Employee Performance. Far East Journal of Psychology and Business , 4-6.

13. Farooq, M., \& Khan, D. M. (2011). Impact of Training and Feedback on Employee Performance. Far East Research Centre, 5 (no.1), 23-33.

14. Foster, R.N. (1986), Innovation: The Attacker's Advantage, Summit Books, New York, NY.

15. Goldstein, I.L. and Gilliam, P. (1990), "Training system issues in the year 2000", AmericanPsychologist, Vol. 45, pp. 134-43.

16. Gruber, H.E. (1996), "The life space of a scientist: the visionary function and other aspects of Jean Piaget's thinking”, Creativity Research Journal, Vol. 9, pp. 251-65.

17. Hampel, P.S. and Martinsons, M.G. (2009). Developing international organizational change theory using cases from China. Human Relations, 62( 4), 459-99.

18. Hennessey, B.A. and Amabile, T.M. (1998), "Reward, intrinsic motivation, and creativity”, American Psychologist, Vol. 53, pp. 674-5.

19. Huselid, M. (1995), "The impact of human resource management practices on 


\section{Macrothink}

turnover, productivity, and corporate financial performance", Academy of Management Journal, Vol. 38, pp. 635-72.

20. Harsanyi, J. (1969), "Rational-choice models of political behaviorvs functionalist and conformist theories", World Politics, Vol. 21, pp. 513-38.

21. Hitt, M.A., Hoskisson, R.E. and Kim, H. (1997), "International diversification effects on innovation and firm performance in product diversified firms", Academy of Management Journal, Vol. 40, pp. 767-98.

22. Jagero, D. N., \& Komba, H. V. (2012). Relationship between on the Job Training and Employee's Performance in Courier Companies in Dar es Salaam, Tanzania. International Journal of Humanities and Social Science , 3-6.

23. Khan, M. I. (2012). Impact of Training and Motivation on performence of employee. Reseach journal of institute of buisiness administration Karachi-Pakistan , 7 (2), 84-95.

24. Lawless, M.W. and Anderson, P.C. (1996), “Generational technological change: effects of innovation and local rivalry on performance", Academy of Management Journal, Vol. 39,pp. 1185-217.

25. Li, Y. and Deng, S.L. (1999), "A methodology for competitive advantage analysis and strategy formulation: an example in a transitional economy", European Journal of Operational Research, Vol. 118, pp. 259-70.

26. Mumford, M.D. and Gustafson, S.B. (1998), "Creativity syndrome: integration, application, and innovation”, Psychological Bulletin, Vol. 103, pp. 27-43.

27. Mumford, M.D. (2000), "Managing creative people: strategies and tactics for innovation", Human Resource Management Review, Vol. 10 No. 3, pp. 313-51.

28. Madsen, S.R., Miller, D. and John, C.R. (2005). Readiness for organizational change: do organizational commitment and social relationships in the workplace make a difference. Human Resource Development Quarterly, 1(2), 213-33.

29. Milne, P. (2007). Motivation, incentives and organisational culture. Journal of Knowledge Management, 11 (6), 28-38.

30. Nohria, N. and Gulati, R. (1996), "Is slack good or bad for innovation?" Academy of Management Journal, Vol. 39, pp. 245-64.

31. Orpen, C. (1994), "Interactive effects of work motivation and personal control on employee job performance and satisfaction”, Journal of Social Psychology, Vol. 134, pp. 855-6.

32. Pavitt, K. (1990), "What we know about strategic management of technology", California Management Review, Vol. 33, pp. 17-126.

33. Quinone's, M.A. (1997), "Contextual influences: on training effectiveness", in 
Quinone's, M.A. and Ehrenstein, A. (Eds), Training for a Rapidly Changing Workplace: Applications of Psychological Research, American Psychological Association, Washington, DC, pp. 177-99.

34. Rudge, A. (2011). Birmingham City Council links increased contribution and outcomes to reward and recognition. Human Resource Management International Digest , 6-8.

35. Saeed, D. M., \& Asghar, M. A. (2012). Examining the Relationship between Training, Motivation and Employees Job Performance - The Moderating Role of Person Job Fit. Journal of Basic and Applied Scientific Research, 2 (12), 12177-12183.

36. Singh, R., \& Mohanty, M. (2012). Impact of Training Practices on Employee Productivity: A Comparative Study. Interscience Management Review, 2 (no.2), 87-92.

37. Sultana, A., Irum, S., Ahmed, K., \& Mehmood, N. (2012). impact of training on employee performance: a study of telecommunication sector in pakistan. nterdisciplinary journal of contemporary research in business, 4 (6), 646-661.

38. U.S., M. (2013). The Impact of Employee Motivation On Organisational Performance. The International Journal Of Engineering And Science (IJES) , 2 (7), 70-80. 